\title{
Whole body vibration and blood glucose levels in elderly people: a pilot study
}

\author{
Vibração de corpo inteiro e níveis de glicemia em idosos: um estudo piloto
}

Maria das Graças Bastos Licurci ${ }^{1} \bowtie$, Alessandra de Almeida Fagundes ${ }^{1}$, Emilia Angela Lo Schiavo Arisawa ${ }^{1}$

${ }^{1}$ Health Sciences College of Vale do Paraíba University. São José dos Campos, SP

\section{ABSTRACT}

AIMS: To evaluate the effect of whole-body vibration therapy on blood glucose levels of elderly people using a vibratory platform.

METHODS: The study included volunteers of both genders, aged between 60 and 75 years, without gait disorders or motor disabilities. Individuals with systemic disease, obesity, conflicting treatments, tobacco users, and those who could not understand the maneuvers were excluded. The study consisted of a single session of whole-body vibration. Heart rate, respiratory rate, arterial blood pressure, and blood glucose were obtained for each participant at baseline, immediately before the procedure. Volunteers were then placed in the standing position on the ground of an oscillating platform and treated for 10 min with a frequency of vibration set at $20 \mathrm{~Hz}$ (displacement $\pm 6 \mathrm{~mm}$; orbital vibration). Immediately after the whole-body vibration session, all data were collected again. Comparisons were made between baseline and post-treatment data. Normality was tested by Kolmogorov-Smirnov test. Data were analyzed using paired Student's t-test or Wilcoxon test as appropriate. The level of significance was set at $\mathrm{p}<0.05$.

RESULTS: Eleven participants (seven men, four women) participated of the study. The mean age was $64.18 \pm 4.37$ years. The results showed a significant decrease in the glycemic indexes $(\mathrm{p}=0.016)$ and an increase in the respiratory rate $(\mathrm{p}=0.047)$ after the whole-body vibration session. CONCLUSIONS: Healthy elderly subjected for 10 minutes to whole-body vibration set at $20 \mathrm{~Hz}$ presented reduction of blood glucose levels and increasing of respiratory rate.

KEY WORDS: aged; whole-body vibration; glycaemia; respiratory rate.

\section{RESUMO}

OBJETIVOS: Avaliar o efeito da terapia da vibração de corpo inteiro nos níveis de glicemia em idosos saudáveis, usando uma plataforma vibratória.

MÉTODOS: O estudo incluiu voluntários de ambos os sexos, com idade entre 60 e 75 anos, sem distúrbios de marcha ou incapacidades motoras. Indivíduos com doença sistêmica, obesidade, tratamentos conflitantes, usuários de tabaco e aqueles que não conseguiram entender as manobras foram excluídos. O estudo consistiu em uma única sessão de vibração de corpo inteiro. A frequência cardíaca, a frequência respiratória, a pressão arterial e a glicemia foram obtidas para cada participante na linha de base, imediatamente antes do procedimento. Os voluntários foram então colocados na posição de pé no piso de uma plataforma oscilante e tratados durante 10 minutos com uma frequência de vibração ajustada em $20 \mathrm{~Hz}$ (deslocamento $\pm 6 \mathrm{~mm}$, vibração orbital). Imediatamente após a sessão de vibração de corpo inteiro, todos os dados foram coletados novamente. Foram feitas comparações entre dados iniciais e do pós-tratamento. A normalidade foi testada pelo teste de Kolmogorov-Smirnov. Os dados foram analisados usando o teste t de Student emparelhado ou o teste de Wilcoxon, conforme apropriado. O nível de significância foi definido em $\mathrm{p}<0,05$.

RESULTADOS: Onze participantes (sete homens e quatro mulheres) participaram do estudo. A média de idade foi de $64,18 \pm 4,37$ anos Os resultados mostraram uma diminuição significativa nos índices glicêmicos $(\mathrm{p}=0,016)$ e um aumento na frequência respiratória $(\mathrm{p}=0,047)$ após a sessão de vibração de corpo inteiro.

CONCLUSÕES: Idosos saudáveis submetidos por 10 minutos à vibração de corpo inteiro, ajustada em $20 \mathrm{~Hz}$, apresentaram redução dos níveis de glicemia e aumento da frequência respiratória.

DESCRITORES: idoso; vibração de corpo inteiro; glicemia; frequência respiratória. 
Abbreviations: WBV, whole-body vibration.

\section{INTRODUCTION}

Active aging depends on the balance between the natural decline of physical abilities and achieving the goal of improving the quality of life as people get older [1]. The aging process comes with challenges, especially the presence of chronic diseases and functional disabilities, which demand new strategies from health professionals [2].

Morbidity indexes present in aging are considered a social problem and must be reviewed regarding the global growth of the elderly population, including in Brazil. Physical activity-based strategies are important because they slow down the natural aging process by maintaining a healthy habit, enabling maintenance of the elderly's life, eliminating the risk of several diseases and promoting quality of life. The benefits of exercise for health are especially valuable in people from the age of $60[3,4]$.

The aging changes may include, in addition to musculoskeletal weakness, a decrease in metabolic capacity parameters. There is evidence that physical activity may have a role in both, causing or attenuating age-related inflammation. Acute and unaccustomed exercise can cause muscle and connective tissue damage, especially in high intensities and for prolonged durations. This damaging response is attenuated if exercise is done repeatedly as the tissue adapts to the new overload stress $[4,5]$.

Currently, the intervention based on wholebody vibration (WBV) carried out on a vibration platform is widely used as an aid to physical activity of the elderly. Regularly performed exercise training on vibratory platforms promoted physiological adaptations such as those observed in aerobic training. WBV can be understood as the alternating motion of a solid body relative to its equilibrium center or as an oscillatory characteristic movement that is repeated around a reference position. Vibration-producing devices are commercially available, being used for physical rehabilitation and for improving physical performance $[6,7]$.

There is evidence that supports the efficacy of WBV in improving cardiorespiratory fitness, muscular performance and body balance in older people [8-11]. Moreover, WBV exercise in elderly contributes to walking ability and promotes effects on postural control [12-13], hormonal profile [14] and neuromuscular performance [15]. Frequency adjustment at $20 \mathrm{~Hz}$ has been used in WBV and is considered secure, with positive effects in postural balance and bone mineral density [9].

However, studies focusing on the acute effects of WBV on cardiovascular and metabolic responses in the elderly population have not been widely conducted, and its application is not very well stablished. The influence of this mechanical stimulus on metabolic and respiratory responses is still unknown. Despite evidence that muscle contractions can change the glucose transport capacity, there is poor information about the effect of vibration training on metabolic responses such as glycemic level, specially in elderly people. Thus, although WBV has been used in recent years as a way of training for elderly people, some questions remained unanswered: Which are the effects of WBV on respiratory and metabolic variables such as heart rate, blood pressure, respiratory rate and blood glucose levels? Are the effects similar to those observed in other types of training, like aerobic training, which reduce blood glucose and increase heart rate? Can these effects be produced with a WBV frequency adjustment of $20 \mathrm{~Hz}$ ?

Therefore, the aim of this study was to determine the acute effects of a $20 \mathrm{~Hz}$ WBV intervention on cardiorespiratory variables and blood glucose levels in elderly subjects.

\section{METHODS}

A prospective pre-post intervention study included subjects of both genders with age between 60-75 years. The sample was non probabilistic and the subjects were recruited from the Supervised Practice Center of Healthy Science Faculty of Vale do Paraíba University (UNIVAP). Elderly without gait disorders or motor disabilities that could limit the use of oscillating platform were eligible for the study. Individuals with systemic disease, obesity, conflicting or ongoing treatments (e.g. cardio-depressive and cardio-stimulating medications), tobacco users, and those who could not understand the maneuvers, were excluded.

The study was approved by the Research Ethics Committee of UNIVAP (protocol number 1.395.981), and the procedures were conducted in accordance with the Declaration of Helsinki. We choice an adequate place to explain the study to the elderly and to invite them to participate. Written informed consent was obtained from all participants after they have been informed about the study's aims and procedures and have agreed to join the study. 
A medical history and anthropometric measures were taken from all subjects to determine the inclusion and exclusion criteria. Heart rate, respiratory rate, arterial pressure, and blood glucose level were obtained for each participant at baseline (just before the intervention). Blood glucose levels were measured using manual lancet and reagent strip with a glucometer (Accu-Check Active Glucose test strips, Roche ${ }^{\circledR}$, Berlim, Germany). Volunteers were then placed in the standing position on the ground of the oscillating platform (Vibra, Nissan ${ }^{\circledR}$, São Paulo, Brazil) and treated for 10 min with a frequency of vibration set at 20 hertz (displacement $\pm 6 \mathrm{~mm}$; orbital vibration). Ten minutes exercise on the oscillating platform was chosen in order to obtain the response at a short training duration. Vibration at $20 \mathrm{~Hz}$ was based on literature, which established this frequency as secure, without collateral effects, and effective in promoting positive effects in parameters such as cardiorespiratory fitness, postural balance and muscle performance [9, 12-13]. Immediately after the WBV training, all data were collected again.

The statistical analysis was carried out using the program Sigma Plot 11.0, Systat ${ }^{\circledR}$, $($ Chicago, IL,
USA). We compare the pre- and post-treatment results. Normality of data was tested by Kolmogorov-Smirnov test, and Student's t-test or Wilcoxon test were used when appropriate. The level of significance was set at $\mathrm{p}<0.05$.

\section{RESULTS}

Thirty-one elderly were eligible for the study, and were recruited. Of these, 20 did not accept to participate, one was obese (body mass index $>34,99 \mathrm{~kg} / \mathrm{m}^{2}$ ), and one had diabetes. Therefore, 11 elderly participated, seven men and four women, with a mean age of $64.18 \pm 4.37$ years (Table 1).

Table 2 shows the cardio-respiratory measurements and blood glucose levels pre- and post-WBV. Respiratory rate increased compared to baseline $(\mathrm{p}=0.016)$; and blood glucose concentration decreased $(p=0.047)$. However, the statistical powers for respiratory rate $(0.09)$ and blood glucose concentration (0.44) were below the desired power (0.80), since the sample size was small. Means of heart rate and arterial pressure did not differ between pre- and post-WBV measures.

Table 1. Age and anthropometric characteristics of the 11 elderly subjects, seven men and four women, included in the study on the effects of whole-body vibration therapy.

\begin{tabular}{lccc}
\hline Participants' characteristics & Mean \pm SD & Median & Range (min-max) \\
Age (years) & $64.18 \pm 4.37$ & 63.0 & $15.0(60-75)$ \\
Weight $(\mathrm{kg})$ & $76.68 \pm 7.28$ & 62.8 & $25.7(62.8-88.5)$ \\
Height $(\mathrm{m})$ & $1.67 \pm 0.092$ & 1.71 & $0.26(1.53-1.80)$ \\
Body mass index $\left(\mathrm{kg} / \mathrm{m}^{2}\right)$ & $27.48 \pm 2.32$ & 25.29 & $14.89(21.46-36.36)$ \\
\hline
\end{tabular}

$\mathrm{SD}$, standard deviation.

Table 2. Cardio-respiratory measurements and blood glucose levels in 11 elderly subjects, seven men and four women, pre- and post- a single 10 minutes session of whole-body vibration with a frequency of $20 \mathrm{~Hz}$, displacement $\pm 6 \mathrm{~mm}$, orbital vibration.

\begin{tabular}{|c|c|c|c|c|}
\hline & Pre-procedure & Post-procedure & p-value & Power \\
\hline Heart rate (beats $/ \mathrm{min})^{1}$ & $75.27 \pm 10.21$ & $74.45 \pm 10.16$ & 0.610 & 0.05 \\
\hline Respiratory rate (movements/min) ${ }^{2}$ & $16(12-21)$ & $18(13-24)$ & 0.016 & 0.09 \\
\hline Systolic blood pressure $(\mathrm{mmHg})^{1}$ & $126.81 \pm 27.12$ & $120.90 \pm 21.24$ & 0.305 & 0.06 \\
\hline Diastolic blood pressure $(\mathrm{mmHg})^{1}$ & $74.81 \pm 10.21$ & $73.54 \pm 10.02$ & 0.541 & 0.05 \\
\hline Blood glucose $(\mathrm{mg} / \mathrm{dL})^{2}$ & $105(88-201)$ & $102(86-170)$ & 0.047 & 0.44 \\
\hline
\end{tabular}

Mean \pm standard deviation (SD), paired Student's t test.

${ }^{2}$ Median (min-max), Wilcoxon test. 


\section{DISCUSSION}

The results of the present study have demonstrated that the exposure to WBV in healthy elderly subjects decreased glucose levels and increased respiratory rate after a relative short time of exposure of $10 \mathrm{~min}$ with oscillating set at $20 \mathrm{~Hz}$. There was no change in other variables.

The decrease in plasma glucose concentration after a single WBV session was probably due to increased rate of glucose uptake into the contracting skeletal muscles, a process regulated by the translocation of GLUT-4, a glucose transporter $[6,16]$. Some studies have shown that a single bout of muscle contractions leads to GLUT 4 translocation to the plasma membrane and transverse tubules of contracting muscles, which acutely enhances glucose transport capacity [6, 16-17].

Di Loreto et al. [17] have studied the effect of a single session of WBV on the endocrine system of 10 healthy individuals and the results showed an increased GLUT 4 translocation. Although similar effects on blood glucose were observed in the present study, several methodological differences can be listed when comparing both studies. Firstly, the mean age of those subjects was 39 \pm 3 years (range 25-50 years), while the present study included only elderly subjects. Additionally, they used a non-continuous $30 \mathrm{~Hz}$ vibration protocol with a duration of $25 \mathrm{~min}$ and rest phases [17]. In contrast, the present study used a continuous $20 \mathrm{~Hz}$ vibration protocol. So, we observed a similar result on an older population, with a lower frequency adjustment, $10 \mathrm{~min}$ duration and without rest intervals.

This exercise mediated process is similar to the action of the insulin on glucose uptake, which also involves translocation of GLUT-4 glucose transporters [6, 16-17]. The present study did not measure GLUT4 translocation to confirm this hypothesis; it was limited to verify blood glucose levels. Besides that, blood samples were taking only in the morning and no other analysis of blood glucose was realized, such as in fasting conditions, which may be considered a limitation of the study. However, to minimize any influences, the comparison was made between blood glucose immediately pre- and post-WBV.

This study was conducted in a small-scale, as a pilot study, and without a matched control group, what cannot rule out the effects from other non-training related factors as placebo effects. Because of the small sample, the statistical power was low for all variables. So it will be necessary to introduce a control group and a larger sample to confirm the benefits of the used protocol on respiratory rate and glycemic levels in elderly people. In addition, comparison between different frequency adjustments and longterm training may provide greater insight regarding cardiorespiratory and metabolic adjustments and adaptations, as well as to determine an optimal training frequency.

We observed an increase in respiratory rate after WBV. Some studies also reported that WBV, similarly to other modalities of exercise, cause changes in ventilatory parameters such as respiratory rate [6-7]. Data about WBV effects on heart rate and arterial blood pressure are inconclusive in the literature [18-20]. WBV could represent a mild form of exercise for the cardiovascular system. Therefore the short time of exposure to WBV exercise (10 $\mathrm{min})$ and the oscillating frequency $(20 \mathrm{~Hz})$ could be responsible for the lack of response of other variables such as heart rate and systolic and diastolic blood pressure.

Despite some limitations, the results herein observed allow to conclude that exposure to WBV in healthy elder subjects after a relative short time of exposure (10 minutes) with oscillating set at $20 \mathrm{~Hz}$ decreased glucose and increased respiratory rate. These results support a beneficial effect of WBV on glycemic control. From a clinical point of view, it would be interesting to observe the effects of WBV in elder individuals with type 2 diabetes mellitus, whose need for drugs could be reduced. Additionally, WBV has special characteristics such as less time needed and patient's passiveness, which can be useful as an exercise type for elderly population with reduced mobility.

\section{NOTES}

\section{Funding}

This study did not receive financial support from outside sources.

\section{Conflicts of interest disclosure}

The authors declare no competing interests relevant to the content of this study. They claim to have had full access to all available data and they take full responsibility for the integrity of the results described herein. 


\section{REFERENCES}

1. Ilha S, Argenta S, Silva MRS, Cezar-Vaz MR, Teda M, Backes DS. Active aging: necessary reflections for nurse/health professionals. Rev fundam care online 2016;8(2):4231-42. https://doi.org/10.9789/2175-5361.2016.v8i2.4231-4242

2. Ozakio Y, Sposito APB, Bueno DRS, Guariento ME. Depression and Chronic disease in the elderly. Rev Soc Bras Clin Med. 2015;13(2):149-53.

3. Miranda GMD, Mendes ACG, Andrade AL. Population aging in Brazil: current and future social challenges and consequences. Rev Bras Geriatr Gerontol 2016; 19(3):507-19. https://doi.org/10.1590/1809-98232016019.150140

4. Woods JA, Wilund KR, Martin SA, Kistler BM. Exercise, Inflammation and Aging. Aging Dis. 2012;3(1):130-40.

5. Pahor M, Guralnik JM, Ambrosius WT, Blair S, Bonds DE, Church TS, Espeland MA, Fielding RA, Gill TM, Groess1 EJ, King AC. Effect of structured physical activity on prevention of major mobility disability in older adults: the LIFE study randomized clinical trial. Jama. 2014;311(23):2387-96. https://doi.org/10.1001/jama.2014.5616

6. Behboudi L, Azarbayjani MA, Aghaalinejad H, Salavati M. Effects of Aerobic Exercise and Whole-Body Vibration on Glycaemia Control in Type 2 Diabetic Males. Asian J Sports Med. 2011;2(2):83-90. https://doi.org/10.5812/asjsm.34789

7. Theodorou A, Gerodimos V, Karatrantou K, Paschalis V, Chanou K, Jamurtas A. Acute and chronic whole-body vibration exercise does not induce health-promoting effects on blood profile. J Hum Kinet. 2015;46:107-18. https://doi.org/10.1515/ hukin-2015-0039

8. Sitjà-rabert M, Rigau D, Vanmeerghaeghe AF, Romero-rodriguez D, Subirana MB, Bonfill X. Efficacy of whole-body vibration exercise in older people: a systematic review. Disabil Rehabil. 2012;34(11):883-93. https://doi.org/10.3109/09 638288.2011 .626486

9. Silva PZ, Schneider RH. Effects of a whole-body vibration platform on postural balance in elderly persons. Acta Fisiatr. 2011;18(1):21-6.

10. Bogaerts AC, Delecluse C, Claessens AL, Troosters T, Boonen S, Verschueren SM. Effects of whole-body vibration training on cardiorespiratory fitness and muscle strength in older individuals (a 1-year randomised controlled trial). Age Ageing. 2009;38:448-54. https://doi.org/10.1093/ageing/afp067

11. Torvinen S, Kannus P, Sievanen H, Jarvinen TA, Pasanen M, Kontulainen S, Jarvinen TL, Jarvinen M, Oja P, Vuori I. Effect of a vibration exposure on muscular performance and body balance. Randomized cross-over study. Clin Physiol Funct Imaging. 2002;22:145-52. https://doi.org/10.1046/j.1365-2281.2002.00410.x

12. Chen CH, Liu C, Chuang L, Chung P, Shian T. Chronic effects of whole-body vibration on jumping performance and body balance using different frequencies and amplitudes with identical acceleration load. J Sci Med Sport. 2014;17:10712. https://doi.org/10.1016/j.jsams.2013.02.010

13. Osugi T, Iwamoto J, Yamazaki M, Takakuwa M. Effect of a combination of whole-body vibration exercise and squat training on body balance, muscle power, and walking ability in the elderly. Ther Clin Risk Manag. 2014;10:131-8.

14. Giunta M, Cardinale M, Agosti F, Patrizi A, Compri E, Rigamonti A.E, Sartorio A. Growth Hormone-Releasing Effects of Whole-Body Vibration Alone or Combined with Squatting plus External Load in Severely Obese Female Subjects. Obes Facts. 2012;4(5):567-74. https://doi.org/10.1159/000342066

15. Furness TP, Maschette WE. Influence of whole-body vibration platform frequency on neuromuscular performance of community-dwelling older adults. J Strength Cond Res. 2009;23:1508-13. https://doi.org/10.1519/JSC.0b013e3181a4e8f9

16. Simmerman EL, Qin X, Berdel HO, Mozaffari MS, Baban B, Yu JC. Alternative Thepapeuthic method for type two diabetes: whole-body vibration therapy: a mini-review. J Pancreas. 2016;17(3):269-76.

17. Di Loreto, C.; Ranchelli,A.; Lucidi, P. et al.Effects of whole-body vibration exercise on the endocrine system of healthy men. J Endocrinol Invest. 2004;27:323-7. https://doi.org/10.1007/BF03351056

18. Avelar NCP, Simão AP, Tossige-Gomes R, Neves CDC, Mezencio B, Szmuchrowski L,Coimbra CC, Lacerda ACR. Oxygen Consumption and Heart Rate During Repeated Squatting Exercises With or Without Whole-Body Vibration in the Elderly. J Strength Cond Res. 2011;25:3495-500. https://doi.org/10.1519/JSC.0b013e3182176664

19. Figueroa A, Vicil F, Sanchez-Gonzalez MA. Acute exercise with whole-body vibration decreases wave reflection and leg arterial stiffness. Am J Cardiovasc Dis. 2011;1:60-7.

20. Robbins D, Yoganathan P, Goss-Samp M. The influence of whole-body vibration on the central and peripheral cardiovascular system. Clin Physiol Funct Imaging. 2014;34(5):364-9. https://doi.org/10.1111/cpf.12103 